\title{
REMARKS ON DEFORMATION IN SNOW WITH RESIDUAL STRESS AND GRAVITATIONAL FORCE BY DETONATION IMPACT
}

\author{
SiAvosh AHMADI \\ Department of Mathematics, \\ Tehran north branch, Islamic Azad University \\ Tehran, Iran. \\ s_ahmadi@iau-tnb.ac.ir
}

\begin{abstract}
Estimation of strain (deformation) and strain energy at the time of an explosion has been undertaken in the present investigation. A basic concept of explosive pressure which is required for the estimation of strain and strain energy has been drawn from the underwater explosion with suitable modification to the present studies. One of the most significant aspects of the present investigation is to augment the model by accounting it for gravitational force and residual stresses which are of realistic in nature. Studies consist of computational aspect by observing the variation of strain and strain energy with respect to material parameters such as Elastic modulus (E), poisons ratio (v), density $(\rho)$, and flow parameters such as peak pressure $\left(\mathrm{P}_{\mathrm{m}}\right)$, sound velocity $\left(\mathrm{V}_{\mathrm{s}}\right)$, and length of snow slab (L). One of the interesting observation found in the computational aspect is, the deformation is found to decrease as the velocity of sound $\left(\mathrm{V}_{\mathrm{s}}\right)$ in snow increases which appears to be strange but found factual. The model has been compared with the other existing papers in the literature and found that, the present model yields to better results.
\end{abstract}

ABSTRAK: Anggaran regangan (canggaan) dan tenaga regangan pada masa letupan diambil kira dalam kajian ini. Konsep asas tekanan letupan yang diperlukan untuk anggaran regangan dan tenaga regangan diperolehi daripada letupan bawah air dengan pengubahsuaian yang sesuai dalam kajian terkini. Antara aspek penting dalam kajian ini adalah penambahan model dengan mengambil kira daya graviti dan tegasan sisa yang sebenar. Kajian terdiri daripada aspek pengiraan, dengan memerhatikan variasi regangan dan tenaga regangan terhadap parameter bahan seperti modulus anjal (E), nisbah Poisson's $(v)$, ketumpatan $(\rho)$, dan parameter aliran seperti tekanan puncak $\left(\mathrm{P}_{\mathrm{m}}\right)$, halaju bunyi $\left(\mathrm{V}_{\mathrm{s}}\right)$, dan panjang papak salji (L). Antara pemerhatian menarik yang ditemui dalam aspek pengiraan ialah, canggaan didapati berkurangan ketika halaju bunyi $\left(\mathrm{V}_{\mathrm{s}}\right)$ salji bertambah. Walaupun ini nampak asing, tetapi ianya terbukti benar. Model dibandingkan dengan kertas kerja lain dan didapati bahawa, model terkini memberikan keputusan yang lebih tepat.

KEYWORDS: avalanche dynamics; fracture mechanics; detonation pressure

\section{INTRODUCTION}

Avalanches in snow bound hilly regions are basically due to instability caused in the snow pack lying on the slopes. The causes for such instability are many. It may be due to pressure metamorphism [1] or due to temperature metamorphism [2] or it may be due to wind induced drift phenomenon [3-4]. The studies on avalanches will not only help in forecasting of it (much before the eventuality to occur) but also in taking precaution for the mitigation aspect (preserving either the structure or the lives once the forces 
(avalanche) can be estimated beforehand). Also, studies help in minimizing the property damage as result of an avalanche. In view of its importance, studies pertaining to avalanches are undertaken in the present investigations. Fracture mechanics deals with the propagation of crack as a result of an impact on the material and the relations there on stress and strain with material properties [Elastic modulus (E), Poison's ratio (v), density $(\rho)$, cross sectional area (A), crack length (a), and so forth] [5-6]. Since instability in snowpack ultimately results into an avalanche, it is understood that, instability may induce cracks in the snowpack before sliding from the top hill. This crack, it is believed that, has links with fracture mechanics for studying stress and strain aspect of snow as a material. Basic concepts of fracture mechanics have been used in analyzing the avalanche related aspects. Avalanches are both natural and artificial one. In a natural avalanche, the release of snow mass from the top of the hill is by the natural phenomenon which is described in the earlier paragraphs. Whereas in artificial ones, the release of an avalanche, is basically due to an explosion in the snowpack from the remote location. This method of artificial triggering is by and large gaining popularity in snow bound hilly regions in the Western Countries since much of the habitation is located in the western part of the globe. Moreover this method is safe and economical one when compared to the destruction (avalanche) it may cause when released naturally. The studies in the present investigations have been basically focused onto the estimation of important flow parameters [velocity and acceleration] during the explosion in the snowpack. In addition to the focused parts, the studies have been also concentrated onto the estimation of other parameters such as strain and strain energy parameters. As is well-known that strain and strain energy is one of the important parameters in the estimation of avalanche formations as a result of an explosion. It is generally noticed during the artificial triggering that, not all explosive detonation results into an avalanche. Though there are various other parameters also required to be estimated ( metamorphic state of snow pack, aging of snow pack, slope aspect and so forth) before going for an avalanche forecasting however, it is generally believed that strain $\left(\varepsilon_{\mathrm{y}}\right)$ and strain energy $\left(\mathrm{E}_{\mathrm{s}}\right)$ are the most effective parameters to estimate and quantify for it during the explosion aspect. In view of its importance of these parameters, the present paper has been stressed on strain $\left(\varepsilon_{\mathrm{y}}\right)$ and strain energy $\left(\mathrm{E}_{\mathrm{s}}\right)$ parameters estimations in addition to velocity and acceleration aspects.

\section{ANALYSIS}

The model has been aimed at first obtaining important flow parameters [velocity, maximum velocity, and acceleration] before going for the determination of strain $\left(\varepsilon_{\mathrm{y}}\right)$ and strain energy $\left(\mathrm{E}_{\mathrm{s}}\right)$.

\section{ESTIMATION OF FLOW PARAMETERS}

The relation between the pressure and velocity at the time of an explosion on the snowpack (lying on slope of hill) is given by [7]

$$
\text { 2.P(t) }-\rho . \mathrm{V}_{\mathrm{s}} \cdot \mathrm{V}=\mathrm{m} \mathrm{dV/dt}
$$

where $\mathrm{P}(\mathrm{t})$ is the pressure, $\mathrm{V}_{\mathrm{s}}$ is velocity of sound in medium, $\mathrm{V}$ is the velocity of projectile, $\rho$ is the density of the water, $m$ is the mass per unit area (water). This relation has been modified to our present requirement of snow as a material. The proposed formula is written as :

$$
\text { 2.P(t) }-\rho . \mathrm{V}_{\mathrm{s}} \cdot \mathrm{V}+\sigma_{\mathrm{g}}-\sigma_{\mathrm{r}}=\mathrm{m} \mathrm{dV/dt}
$$


where $\sigma_{\mathrm{g}}, \sigma_{\mathrm{r}} \rho$, and $\mathrm{V}$ are gravitational and residual stress, density of snow, and velocity of the snow pack respectively. $\mathrm{P}(\mathrm{t})$ is taken to be of the form from Ref. [8] as

$$
\mathrm{P}(\mathrm{t})=\mathrm{P}_{\mathrm{m}} \cdot \exp (-\mathrm{t} / \mathrm{T})
$$

where $P_{m}$ is the peak pressure, $t$ is the time, and $T$ is the time decay factor. This peak pressure is due to an explosion. Schewizer [9] has correlated the term $\left(\sigma_{\mathrm{g}}-\sigma_{\mathrm{r}}\right)$ to snow density $(\rho)$, gravity (g), and to slab depth by (Fig. 1)

$$
\sigma_{\mathrm{g}} / \sigma_{\mathrm{r}}=1.5, \quad \sigma=\sigma_{\mathrm{g}}-\sigma_{\mathrm{r}}=(1 / 3) \text { p.g.H. } \sin \theta
$$

where $\mathrm{H}$ is snow slab depth and $\theta$ is the slope angle. This relation [eqn.(4)] has been successfully employed in our earlier studies [10].

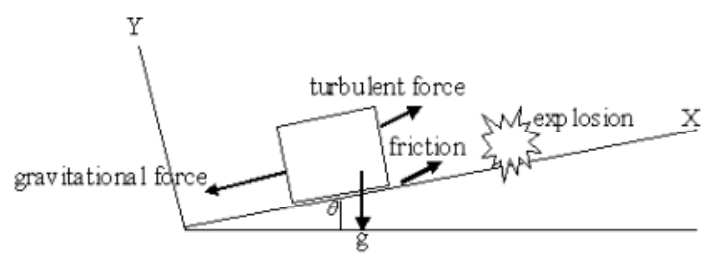

Fig. 1: Flow geometry.

In order to solve eqn.(2), we need to have one condition (initial or boundary) and this has been taken to be of the from $\mathrm{V}(0)=0$. Using this condition eqn.(2) simplifies to

$$
\begin{aligned}
\mathrm{V}(\mathrm{t})= & {\left[2 \cdot \operatorname{Pm} \cdot \mathrm{T} /\left(\rho \cdot\left(\mathrm{L}-\mathrm{V}_{\mathrm{s}} \cdot \mathrm{T}\right)\right)\right] \cdot\left\{\exp \left(-\mathrm{V}_{\mathrm{s}} / \mathrm{L}\right)-\exp (-\mathrm{t} / \mathrm{T})\right\}+} \\
& {[(\mathrm{g} \cdot \mathrm{H} \cdot \sin \theta) / 3] \cdot\left\{1-\exp \left(-\mathrm{V}_{\mathrm{s}} \cdot \mathrm{t} / \mathrm{L}\right)\right\} }
\end{aligned}
$$

having known velocity, maximum velocity of the snowpack $\left(\mathrm{V}_{\max }\right)$ soon after the explosion can be estimated by equating its gradient to zero. That is $\mathrm{dV} / \mathrm{dt}=0$. Taking differential of (5) with respect to ' $t$ ' and equating it to zero we get the time to achieve this maximum velocity.

$$
\mathrm{tV}_{\max }=\mathrm{L} \cdot \mathrm{T} \cdot \ln \left\{\left[\sigma \cdot\left(\mathrm{T} \cdot \mathrm{V}_{\mathrm{s}}-\mathrm{L}\right)+2 \cdot \mathrm{P}_{\mathrm{m}} \cdot \mathrm{V}_{\mathrm{s}} \cdot \mathrm{T}\right] /\left(2 \cdot \mathrm{P}_{\mathrm{m}} \cdot \mathrm{L}\right)\right\} /\left(\mathrm{V}_{\mathrm{s}} \cdot \mathrm{T}-\mathrm{L}\right)
$$

Substituting this ' $\mathrm{t}_{\mathrm{Vmax}}$ ' for ' $\mathrm{t}$ ' in equation (5), we get maximum velocity $\left(\mathrm{V}_{\max }\right)$ as:

$$
\begin{aligned}
\mathrm{V}_{\max }= & {\left[2 \cdot \mathrm{P}_{\mathrm{m}} \cdot \mathrm{T} /\left(\rho \cdot\left[\mathrm{L}-\mathrm{V}_{\mathrm{s}} \cdot \mathrm{T}\right]\right)\right] \cdot\left\{\left\{\left[\sigma \cdot\left(\mathrm{V}_{\mathrm{s}} \cdot \mathrm{T}-\mathrm{L}\right)+2 \mathrm{P}_{\mathrm{m}} \mathrm{V}_{\mathrm{s}} \cdot \mathrm{T}\right] /\left(2 \cdot \mathrm{P}_{\mathrm{m}} \cdot \mathrm{L}\right)\right\}_{\mathrm{s}}^{\mathrm{V} \cdot \mathrm{T} /\left(\mathrm{L}-\mathrm{V}_{\mathrm{s}} \cdot \mathrm{T}\right)}-\{\right.} \\
& {\left.\left.\left.\left[\sigma \cdot\left(\mathrm{V}_{\mathrm{s}} \cdot \mathrm{T}-\mathrm{L}\right)+2 \mathrm{P}_{\mathrm{m}} \mathrm{V}_{\mathrm{s}} \cdot \mathrm{T}\right] /\left(2 \cdot \mathrm{P}_{\mathrm{m}} \cdot \mathrm{L}\right)\right\}^{\mathrm{L} /\left(\mathrm{L}-\mathrm{V}_{\mathrm{s}} \mathrm{T}\right)}\right\}\right\}+\sigma /\left(\rho \cdot \mathrm{V}_{\mathrm{s}}\right)\left[1-\left\{\left[\sigma \cdot\left(\mathrm{V}_{\mathrm{s}} \cdot \mathrm{T}-\mathrm{L}\right)+\right.\right.\right.} \\
& \left.\left.2 \mathrm{P}_{\left.\left.\mathrm{m} \cdot \mathrm{V}_{\mathrm{s}} \cdot \mathrm{T}\right] /\left(2 \cdot \mathrm{P}_{\mathrm{m}} \cdot \mathrm{L}\right)\right\}_{\mathrm{s}}^{\mathrm{V}} \cdot \mathrm{T} /\left(\mathrm{L}-\mathrm{V}_{\mathrm{s}} \cdot \mathrm{T}\right)}\right\}\right]
\end{aligned}
$$

Knowing velocity from equation (5), acceleration can be obtained by taking differentiation with respect to " $t$ ". That is

$$
\begin{aligned}
\mathrm{a}(\mathrm{t})= & \mathrm{dV}(\mathrm{t}) / \mathrm{dt}=\left[2 \cdot \operatorname{Pm} \cdot \mathrm{T} /\left(\rho \cdot\left(\mathrm{L}-\mathrm{V}_{\mathrm{s}} \cdot \mathrm{T}\right)\right)\right] \cdot\left\{\left(-\mathrm{V}_{\mathrm{s}} / \mathrm{L}\right) \exp \left(-\mathrm{V}_{\mathrm{s}} \mathrm{t} / \mathrm{L}\right)+(1 / \mathrm{T}) \exp (-\mathrm{t} / \mathrm{T})\right\}+ \\
& {[(\mathrm{g} \cdot \mathrm{H} \cdot \sin \theta) / 3] \cdot\left\{\left(\mathrm{V}_{\mathrm{s}} / \mathrm{L} \exp \left(-\mathrm{V}_{\mathrm{s}} \cdot \mathrm{t} / \mathrm{L}\right)\right\}\right.}
\end{aligned}
$$

\section{Estimation of Strain and Strain Energy}

From the classical theory of elasticity [5,6], deformation energy $\left(\mathrm{W}_{\mathrm{def}}\right)$, stress $\left(\sigma_{\mathrm{yy}}\right)$ in y direction, and strain $\left(\varepsilon_{\mathrm{y}}\right)$ are related by 


$$
\mathrm{W}_{\mathrm{def}}=\int \sigma_{\mathrm{yy}} \mathrm{d} \varepsilon_{\mathrm{y}}
$$

where $\sigma_{\mathrm{yy}}$ and $\varepsilon_{\mathrm{y}}$ are normal stress and normal strain respectively. $\sigma_{\mathrm{yy}}$ and $\varepsilon_{\mathrm{y}}$ are related by [5-6]

$$
\begin{aligned}
& \varepsilon_{\mathrm{x}}=\left[\sigma_{\mathrm{xx}}-v\left(\sigma_{\mathrm{yy}}+\sigma_{\mathrm{zz}}\right)\right] / \mathrm{E} \\
& \varepsilon_{\mathrm{y}}=\left[\sigma_{\mathrm{yy}}-v\left(\sigma_{\mathrm{xx}}+\sigma_{\mathrm{zz}}\right)\right] / \mathrm{E}
\end{aligned}
$$

where $\mathrm{E}, v, \sigma_{\mathrm{xx}}, \sigma_{\mathrm{yy}}, \sigma_{\mathrm{zz}}, \varepsilon_{\mathrm{x}}$ are Elastic modulus, Poison's ratio, normal stress in $\mathrm{x}, \mathrm{y}$ and $\mathrm{z}$ directions, and normal strain in the x-direction respectively. Assuming $\sigma_{\mathrm{zz}}$ and $\varepsilon_{\mathrm{x}}$ both equal to zero, eqn.(10) and (11) simplifies to

$$
\begin{aligned}
& \varepsilon_{\mathrm{y}}=(1 / \mathrm{E}) \sigma_{\mathrm{yy}}\left(1-v^{2}\right) \\
& \sigma_{\mathrm{yy}}=\mathrm{E} \cdot \varepsilon_{\mathrm{y}} /\left(1-v^{2}\right)
\end{aligned}
$$

we also know that Kinetic energy $\left(\mathrm{K}_{\mathrm{E}}\right)\left[\mathrm{W}_{\mathrm{k}}\right]$ is related by

$$
\mathrm{K}_{\mathrm{E}}=\mathrm{W}_{\mathrm{k}}=1 / 2 \mathrm{~m} \cdot \mathrm{V}^{2}{ }_{\max }
$$

It is assumed that, explosion energy is same as the deformation (strain) energy and is equated to kinetic energy. we get

$$
1 / 2 \rho \cdot V^{2}{ }_{\max }=\left\{\mathrm{E} /\left[2 \cdot\left(1-v^{2}\right)\right] \cdot\right\} \varepsilon_{\mathrm{y}}^{2}
$$

substituting for $\mathrm{V}_{\max }$ from equation (7) in eqn.(15), we get deformation (normal $\operatorname{strain}\left(\varepsilon_{\mathrm{y}}\right)$ ) as:

$$
\begin{aligned}
\varepsilon_{\mathrm{y}}= & {\left[\rho \cdot\left(1-v^{2}\right) / \mathrm{E}\right]^{0.5} \cdot\left[2 \cdot \mathrm{P}_{\mathrm{m}} \cdot \mathrm{T} /\left(\rho \cdot\left[\mathrm{L}-\mathrm{V}_{\mathrm{s}} \cdot \mathrm{T}\right]\right)\right] \cdot\left\{\left\{\left[\sigma \cdot\left(\mathrm{V}_{\mathrm{s}} \cdot \mathrm{T}-\mathrm{L}\right)+\right.\right.\right.} \\
& \left.\left.\left.\left.2 \mathrm{P}_{\mathrm{m}} \mathrm{V}_{\mathrm{s}} \cdot \mathrm{T}\right] /\left(2 \cdot \mathrm{P}_{\mathrm{m}} \cdot \mathrm{L}\right)\right\}_{\mathrm{s}}^{\mathrm{V} \cdot \mathrm{T} /\left(\mathrm{L}-\mathrm{V}_{\mathrm{s}} \cdot \mathrm{T}\right)}-\left\{\left[\sigma \cdot(\mathrm{c} \cdot \mathrm{T}-\mathrm{L})+2 \cdot \mathrm{P}_{\mathrm{m}} \cdot \mathrm{V}_{\mathrm{s}} \cdot \mathrm{T}\right] /\left(2 \cdot \mathrm{P}_{\mathrm{m}} \cdot \mathrm{L}\right)\right\}^{\mathrm{L} /(\mathrm{L}-\mathrm{V} \cdot \mathrm{s})}\right\}\right\} \\
& \left.+\sigma /\left(\rho \cdot \mathrm{V}_{\mathrm{s}}\right)\left[1-\left\{\left[\sigma \cdot\left(\mathrm{V}_{\mathrm{s}} \cdot \mathrm{T}-\mathrm{L}\right)+\mathrm{P}_{\mathrm{m}} \cdot \mathrm{V}_{\mathrm{s}} \cdot \mathrm{T}\right] /\left(2 \cdot \mathrm{P}_{\mathrm{m}} \cdot \mathrm{L}\right)\right\}_{\mathrm{s}}^{\mathrm{V} \cdot \mathrm{T} /\left(\mathrm{L}-\mathrm{V}_{\mathrm{s}} \cdot \mathrm{T}\right)}\right\}\right]
\end{aligned}
$$

substituting $\varepsilon_{\mathrm{y}}$ in equation (13) and using eqn.(9) we get strain energy $\left(\mathrm{E}_{\mathrm{s}}\right)$ which is assumed to be same as deformation energy $\left(\mathrm{W}_{\mathrm{def}}\right)$ as:

$$
\mathrm{E}_{\mathrm{s}}=\left\{\mathrm{E} /\left[2 \cdot\left(1-v^{2}\right)\right] \cdot\right\} \varepsilon_{\mathrm{y}}^{2}
$$

\section{RESULTS AND DISCUSSION}

Flow parameters velocity $(\mathrm{V})$, acceleration (a), maximum velocity $\left(\mathrm{V}_{\max }\right)$, strain $\left(\varepsilon_{\mathrm{y}}\right)$, and strain energy $\left(\mathrm{E}_{\mathrm{s}}\right)$ have been computed and their variation have been observed with material parameters such as density, velocity of sound in the medium, elastic modulus (E), and Poison's ratio. The computed values have been shown in Fig. 2-6. The present computed values have been compared with the model having no gravitational and residual stress [10]. In order to compute flow parameters we need data on peak pressure $P_{m}, \rho, E$, $\mathrm{T}, \mathrm{t}, v, \varepsilon_{\mathrm{y}}$, and the same has been taken from Ref [11-12]. These data have been shown in Table 1. The results indicate, the present computed values are lower (except for density, and velocity of sound $\mathrm{V}_{\mathrm{s}}$ ) in comparison to without gravitation and residual stresses [the solid line in Fig. 2-6 indicate for without gravitation and residual stresses]. The reason for such lower values could be attributed due to inclusions of the more realistic parameters in the present investigations which resulted into more accurate values. One of the 
interesting observations of velocity computation is, the present variations of $\mathrm{V}$ with $\mathrm{V}_{\mathrm{s}}$ is found to be increasing and realistic whereas without gravitational and residual terms is found decreasing. The reason for this discrepancy could be basically due to subtraction of velocity of sound from peak pressure terms [eqn.(2)]. The time delay factor T did not find much effect on the maximum velocity computations [Fig. 3].The results on acceleration [Fig. 4] is found to be very distinct when compared with and without gravitational and residual stresses. The justification for this discrepancy could be given in similar conjunction with that of velocity computations. The variation of acceleration with $\mathrm{P}_{\mathrm{m}}$ [Fig. 4] also found not to yield significant variations in comparison to earlier model [10]. The results on strain $\left(\varepsilon_{\mathrm{y}}\right)$ with $\mathrm{V}_{\mathrm{s}}$, $\mathrm{L}$ (slab length) and $\mathrm{T}$ indicates that, the addition of gravitation and residual increases the strain component whereas with $\mathrm{P}_{\mathrm{m}}$ and $\rho$ it decreases [Fig. 5]. The variation of strain energy $\left(\mathrm{E}_{\mathrm{s}}\right)$ with $\mathrm{E}, v$, and with $\varepsilon_{\mathrm{y}}$ shows that, strain energy increases with increase in E, $v$ and $\varepsilon_{\mathrm{y}}$ [Fig. 6]. Also it is observed that, the present computed values of $E_{\mathrm{s}}$ with $\varepsilon_{\mathrm{y}}$ are found to be greater than that of without gravitational and residual stress. All the computed results [Fig. 2-6] have found to agree with the physics of flows and deformation property. For instance, increase in strain with peak pressure and decrease with elastic modulus adheres to results from classical physics.

Table 1: Data of flow parameters.

\begin{tabular}{|l|c|c|}
\hline \multicolumn{1}{|c|}{ Parameters } & Typical values & Range \\
\hline Peak pressure $: \mathrm{P}_{\mathrm{m}}$ & $300 \mathrm{pa}$ & $200-300$ \\
\hline Distance of blast center: $\mathrm{r}$ & $90 \mathrm{~m}$ & $90-9000$ \\
\hline Time decay $: \mathrm{T}$ & $3 \mathrm{~s}$ & $2-15$ \\
\hline Arrival time $: \mathrm{t}$ & $0.1 \mathrm{~s}$ & $0-2$ \\
\hline Density $: \rho$ & $200 \mathrm{~kg} / \mathrm{m}^{3}$ & $100-400$ \\
\hline Slab length $: \mathrm{L}$ & $4 \mathrm{~m}$ & $2-8$ \\
\hline Sound speed in snow $: \mathrm{V}_{\mathrm{s}}$ & $300 \mathrm{~m} / \mathrm{s}$ & $100-300$ \\
\hline Elastic modulus $: \mathrm{E}$ & $10 \mathrm{Mpa}$ & $0.5-10$ \\
\hline Poison ratio $: v$ & 0.2 & $0.1-0.3$ \\
\hline Strain $: \varepsilon_{\mathrm{y}}$ & $5.7 \times 10^{-5}$ & $2 \times 10^{-5}-10^{-4}$ \\
\hline
\end{tabular}



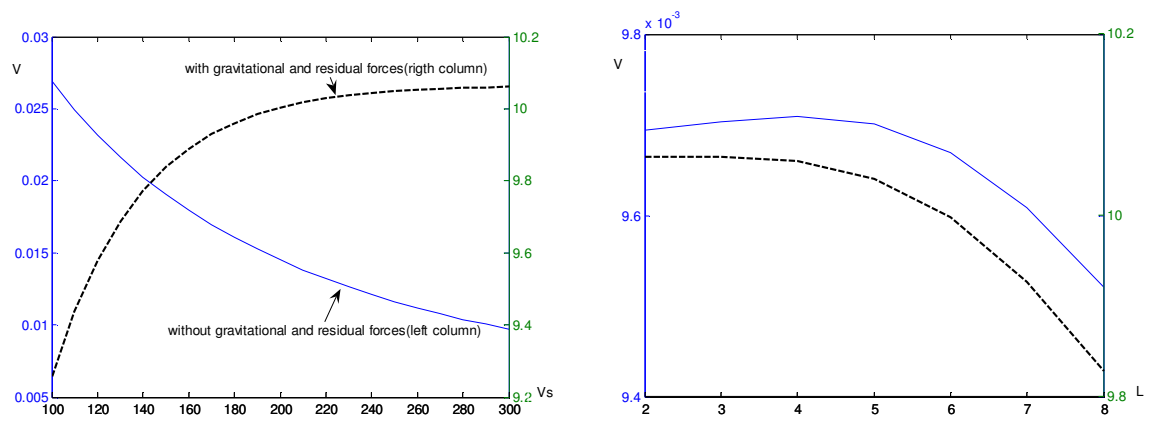

Fig. 2: Variation of velocity $(\mathrm{V})$ with flow parameters $\left(\mathrm{V}_{\mathrm{s}}, \mathrm{L}\right)$.

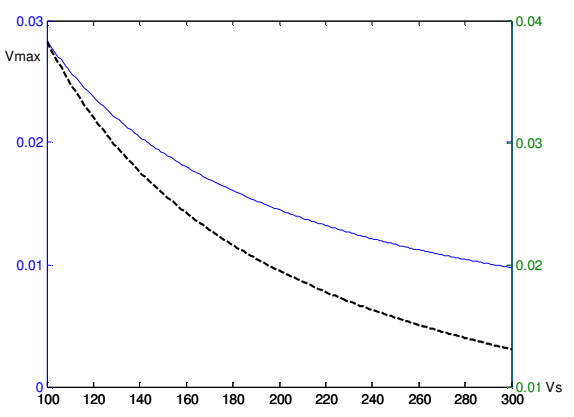

Fig. 3: Variation of maximum velocity $\left(\mathrm{V}_{\max }\right)$ with flow parameters $\left(\mathrm{V}_{\mathrm{s}}, \mathrm{L}\right)$.
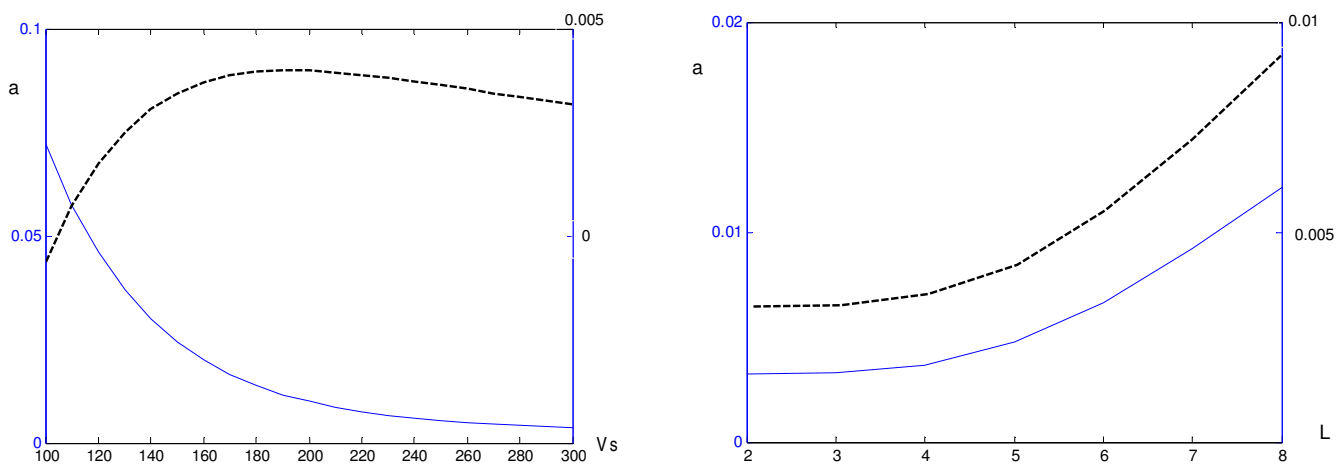

Fig. 4: Variation of acceleration (a) with flow parameters $\left(V_{s}, L\right)$.
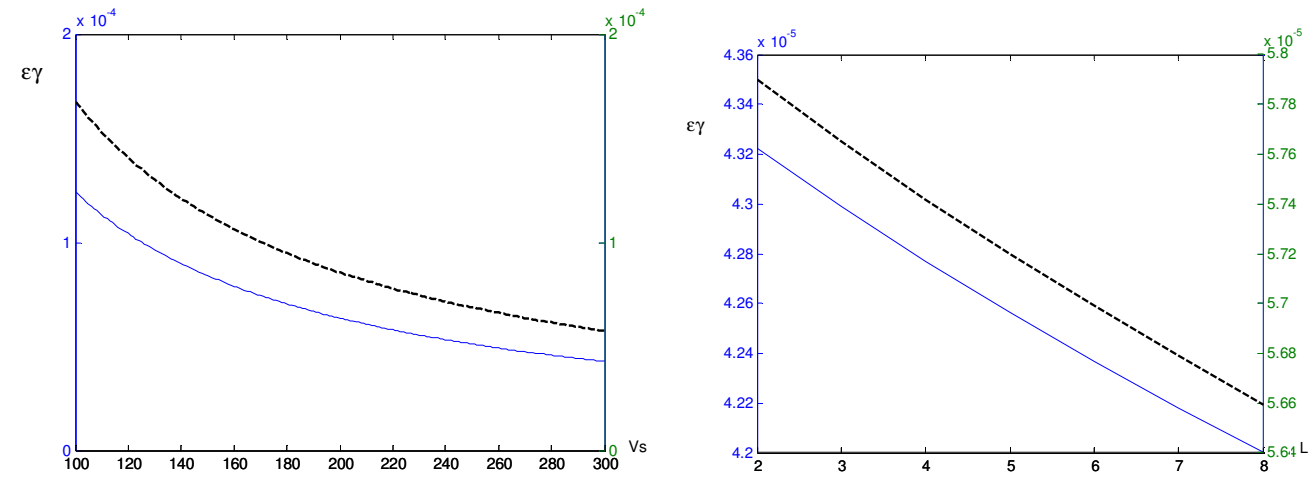

Fig. 5: variation of strain $\left(\varepsilon_{\mathrm{y}}\right)$ with flow parameters $\left(\mathrm{V}_{\mathrm{s}}, \mathrm{L}\right)$. 

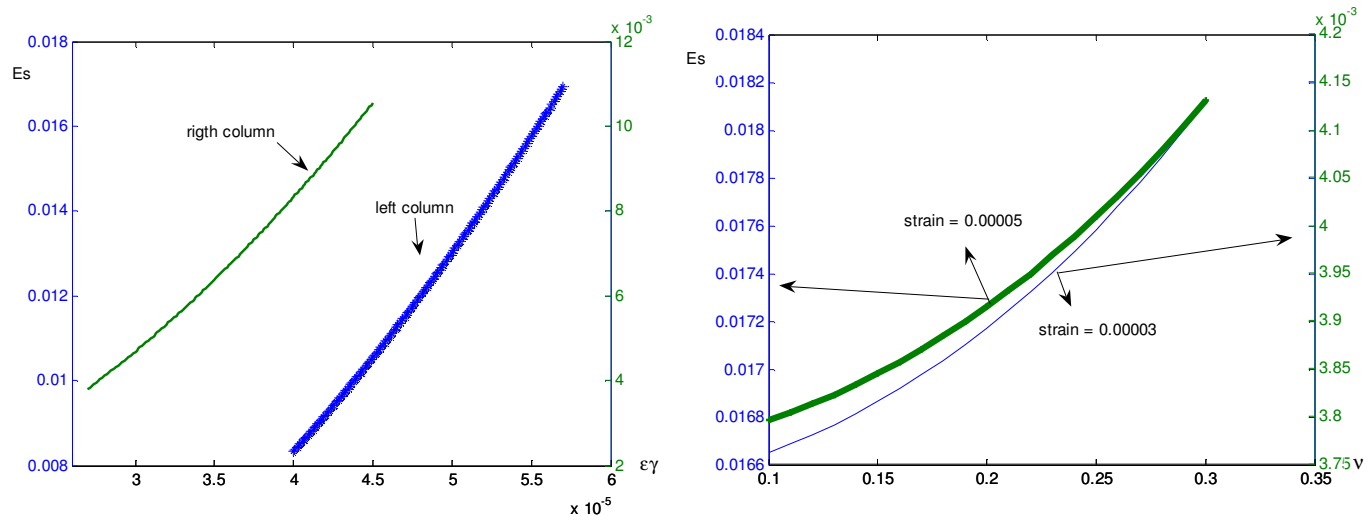

Fig. 6: Variation of strain energy with strain, elastic modulus.

\section{CONCLUSION}

The present studies deal with the estimation of strain and strain energy at the time of an explosion as these parameters plays significant role in forecasting of an avalanche. The model has been developed with the basic concepts from underwater explosions with suitable modification to the present model. The flow variables (velocity, maximum velocity, and acceleration, strain and strain energy) have been computed for various material parametric effects (density, peak pressure, slab length, elastic modulus, poisons ratio, velocity of sound in medium) and found that the present computed results yield better results when compared with the earlier models. Also, the model observed to yield the results which could be quantifiable with the physics of flow and deformation theory from classical theories. The results need to be quantifiable with the avalanche formation which is our continued effort.

\section{REFERENCES}

[1] Palmer,A.G and J.R.Rice.The growth of slip surfaces in the progressive failure of overconsolidated clay.Proc.R.Sac.London.Scr.A, 332 (1591),518-527,1973.

[2] P.S.Negi, R.K Aggrawal, D N Sethi and Uttam Chand, "Measurment of thermal conductivity of seasonal snow by a pc based transient thermal probe method", Proceedings International Symposium on Snow Monitoring and Avalanches(ISSMA-2004), Snow and Avalanche Study Establishment(SASE), Manali, India, 67-70(2004).

[3] RONALD I, PERLA M, AND MARTINELLI.Jr,"AVALANCHE HAND BOOK" U.S.Dep.Agric.,Agric.Handb.489,254p,1978.

[4] PAUL M.B.FOHN,"SNOW TRANSPORT OVER MOUNTAIN CRESTS", journal of Glaciology,Vol 26,469-492,(1980)

[5] Dowling. N.E. : Mechanical behavior of materials (1993).M. Young, The Technical Writer's Handbook. Mill Valley, CA: University Science, 1989.

[6] Kannien, M.F. and Popelar, C.H.: Advanced Fracture Mechanics Oxford University Press (1985).

[7] Hollyer RS. Direct shock-wave damage to merchant ships from non-contact derwater explosion. Trans SNAME 1959;67:773-84.

[8] C.F. Hunga,*, P.Y. Hsua, J.J. Hwang-Fuub: Elastic shock response of an air-backed plate to underwater explosion(in detonation file). Trans SNAME 2005:151-158.

[9] Schweizer J. Review of Dry Snow Slab Avalanche Release. J. Cold Region Science and Technology, 30, 43-57 (1999). 
[10] Siavosh Ahmadi and R.N. Pralhad: Modeling propagation of explosive shock waves in snow on hilly top and prediction towards an avalanche release, Proceedings 34 National Society For Fluid Mechanics and Fluid Power, BITS Mesra Ranchi, Dec. 10-12, 2007.

[11] Donald Albert: Reduction of blast noise by a snow cover, Primary subject classification: 21.3.4; Secondary subject classification: 72.8, 2002.

[12] Virendra Kumar and H. Muthurajan : "Artificial triggering of avalanches using explosives", Proceedings International Symposium on Snow Monitoring and Avalanches(ISSMA-2004): Snow and Avalanche Study Establishment(SASE), Manali, India., 137-144, 2004. 